\title{
PEMAHAMAN KEBERAGAMAAN DAN GERAKAN KELOMPOK FPI SURABAYA
}

\author{
Syamsul Ma'arif \\ Mahasiswa Program Doktor Universit as Negeri Yogyakarta (UNY) \\ Kampus Karangmalang Yogyakarta \\ e-mail: syamsulmaarif1974@yahoo.co.id
}

\begin{abstract}
Attitudes of FPI (Islamic Defenders Front) in Indonesia so far impressed 'frontal' and against any form of indecent behavior. Their action, in fact it can be said as one of the deepest expression of a group of Muslims in articulating religious teachings are embraced, or as an attitude of "piety" in viewing of all the different faiths in the belief that he believes. Especially in view of problems that are clearly regarded as a form of disobedience, apostasy and blasphemy. The responses and reactions, as well as research that has been conducted by the author in Surabaya is in order to uphold the principles of faith are considered "correct" earlier. This paper aims to provide comprehensive information on what factors underlie the birth of contemporary religious groupsparticularly FPI in Surabaya. And find the religious understanding, activity and movements FPI group in the area. Overview of the results of this study are expected to eventually be able to eliminate the possibility of misunderstanding information is the cause of the onset of prejudice and stereotypes is the first step in conflict or resolve conflicts between religious communities in a comprehensive manner. Therefore, the known diversity of religious groups with the dynamics of movements will make it easier for religious communities to learn from each other.
\end{abstract}

Abstrak: Sikap-sikap FPI (Front Pembela Islam) di Indonesia selama ini
terkesan 'frontal' dan melawan setiap bentuk kemungkaran. Aksi
mereka, sebenarnya bisa dikatakan sebagai salah satu bentuk ekspresi
terdalam dari sekelompok orang muslim dalam mengartikulasikan
ajaran-ajaran agama yang dipeluknya, atau sebagai bentuk sikap
"kesalehan" dalam memandang setiap keyakinan yang berbeda dengan
keyakinan yang diyakininya. Apalagi dalam memandang persoalan yang
jelas-jelas dianggap sebagai bentuk kemaksiatan, kesesatan dan
penodaan agama. Maka respons dan reaksi mereka, sebagaimana hasil
penelitian yang telah dilakukan penulis di Surabaya adalah dalam rangka
menegakkan prinsip keimanan yang dianggap "benar" tadi. Tulisan ini

TEOLOGIA, VOLUME 23, NOMOR 2, JULI-DESEMBER 2012 
SYAMSUL MA'ARIF: Pemahaman Keberagamaan dan Gerakan ...

bertujuan untuk memberikan informasi yang komprehensif tentang faktor apa saja yang melatari lahirnya kelompok-kelompok keagamaan kontemporer - terutama sekali FPI di Surabaya. Sekaligus mengetahui pemahaman keagamaan, aktifitas dan gerakan-gerakan kelompok FPI di daerah tersebut. Gambaran hasil penelitian ini pada akhirnya diharapkan mampu mengeliminasi kemungkinan kesalahpahaman informasi yang menjadi sebab timbulnya prejudice, dan stereotype yang mernpakan langkah awal terjadinya konflik atau mengatasi konflik antar komunitas agama secara komprehensif. Sebab, dengan diketahui keanekaragaman kelompok-kelompok keagamaan dengan dinamika gerakannya akan lebih memudahkan masyarakat agama untuk saling belajar satu sama lain.

Keywords: Pemahaman Keberagamaan, Gerakan, FPI Surabaya, liberalisme, $N U$, Muhammadiyah.

\section{A. Pendahuluan}

Era reformasi dengan segala agendanya, ternyata masih menyisakan problem tersendiri bagi masyarakat Indonesia. Di antaranya adalah gejala keagamaan di Indonesia kontemporer menunjukkan gejala-gejala yang saling "bertentangan" dengan cita-cita demokrasi. ${ }^{1}$ Tuntutan otonomi individu, self expression, self realization, misalnya, bersamaan dengan munculnya gejala komunalisme yang muncul di berbagai daerah. Gelombang spiritualisme pada saat yang sama juga berbarengan dengan semakin menguatnya gerakan formalisme agama, yang berujung pada perilaku anarkisme dan kekerasan.

Tidak bisa dipungkiri, pasca reformasi dengan agenda utamanya "demokratisasi" telah menyebabkan masyarakat Indonesia merasa dibuka dan diberi kebebasan untuk menyuarakan aspirasi pendapat dan politiknya, setelah sekian lama merasa dikebiri oleh pemerintah Orde Baru. Ditandai dengan keterbukaan, partai politik tumbuh bak cendawan di musim penghujan, organisasi budaya berkembang pesat, begitu juga dengan organisasi keagamaan. Semua berkembang dan mencoba mencari jati diri. Dalam hal organisasi keagamaan yang berkembang pesat adalah mereka yang berorientasi fundamentalis, ${ }^{2}$ karena pada masa-masa sebelumnya mereka tidak bisa bergerak akibat kekuasaan otoriter Orde Baru yang selalu mencoba untuk memarginalkan mereka. 
SYAMSUL MA'ARIF: Pemahaman Keberagamaan dan Gerakan ...

Sebagaimana analisis para ahli, sebenarnya gerakan Islam pasca reformasi terbagi menjadi beberapa varian pemikiran dan gerakan. Semuanya bisa dipetakan dan ditelusuri akar-akarnya menjadi dua arus pemikiran utama yang sangat dominan yakni literalisme dan liberalisme. ${ }^{3}$ Kelompok Islam literal biasanya mengusung ide-ide dan pemahaman keislaman yang "eksklusif". Sedangkan kelompok liberalisme lebih terbuka, dan meminjam terminology Kurzman ${ }^{4}$ diukur berdasarkan enam state of mind, yakni sikap terhadap teokrasi, demokrasi, hak-hak perempuan, hak-hak non-muslim, kebebasan berpikir, dan progresifitas atau kemajuan.

Kedua kelompok tersebut memang telah memberikan "warna" tersendiri bagi kehidupan beragama dan bernegara di Indonesia. Kita bisa menyaksikan banyak sekali gerakan-gerakan Islam yang muncul dan menegaskan identitas mereka masing-masing. Menariknya baik kelompok-kelompok yang masuk dalam katagori literalisme maupun liberalisme, sama-sama kecewa dengan ormas-ormas besar seperti NU dan Muhammadiyah. ${ }^{5}$ Kalau kelompok literalis menggangap kedua organisasi besar ini tidak tegas dalam memperjuangkan aspirasi Islam. Sedangkan kelompok yang masuk dalam katagori liberalis menganggap NU dan Muhammadiyah sudah mulai kurang responsif terhadap isu-isu baru.

Untuk menyebut contoh-contoh yang termasuk dalam katagori Islam literalis adalah Hizbut Tahrir Indonesia (HTI), Majelis Mujahidin Indonesia (MMI), Front Pembela Islam (FPI), Laskar Jihad (LJ), dan Kesatuan Aksi Mahasiswa Muslim Indonesia (KAMMI). Model pemikiran gerakannya adalah adanya legalisasi Islam dalam sistem sosial ataupun politik Indonesia. Sedangkan yang termasuk dalam Islam Liberalis adalah JIL (Jaringan Islam Liberal), Post-Tra (Post-Tradisionalisme) dan JIMM (Jaringan Intelektual Muda Muhammadiyah).

Munculnya kelompok-kelompok agama dengan varian dan modelnya seperti tersebut di atas, sebenarnya adalah sah-sah saja. Asal semua masih dalam kontek NKRI dan koridor demokrasi. Tanpa ada inisisiatif memvonis keberadaan "mereka", barangkali fenomena di atas menunjukkan gejala signifikan yang harus direspon oleh umat Islam. Dan perlu dipahami, kebangkitan kaum "fundamentalis" sebenarnya

TEOLOGIA, VOLUME 23, NOMOR 2, JULI-DESEMBER 2012 
SYAMSUL MA'ARIF: Pemahaman Keberagamaan dan Gerakan ...

bukanlah sebuah ancaman serius bagi kelompok atau golongan lain. Hanya saja, fenomena kekerasan beragama di Indonesia baru-baru ini, memang jika kita telusuri di samping karena alasan politis, juga karena motivasi-motivasi keagamaan para kaum fundamentalis, seperti jihad, yang mengakibatkan adanya tindakan-tindakan yang mengancam masa depan umat Islam itu sendiri. ${ }^{6}$

Di samping itu, masih banyaknya masyarakat yang belum mengerti betul hakikat dan sejatinya demokrasi sebenarnya adalah kondisi yang sangat menghawatirkan dan perlu segera dicarikan jalan keluarnya. Tak jarang, disinilah sebetulnya letak titik rawannya, karena banyak sekali kelompok-kelompok kegamaan tertentu dengan dalih menyuarakan aspirasi yang mewakili dari kelompok mayoritas, terkadang harus menimbulkan ketidak adilan dan diskriminasi terhadap kelompok minoritas. $^{7}$ Akibatnya adalah, tension atau ketegangan dan konflik kepentingan diantara masyarakat yang memiliki keanekaragaman agama, etnis dan budaya.

\section{B. Gambaran Kelompok FPI Surabaya}

Adalah merupakan suatu fakta sejarah, mayoritas masyarakat Indonesia beragama Islam atau sekitar $85,2 \%$ dari dua ratus juta orang. ${ }^{8}$ Meskipun begitu, apa yang menjadi prinsip dasar bagi agama Islam, yaitu terwujudnya masyarakat yang benar-benar menjalankan syari'at agama Islam belum dapat terlaksana dengan baik. Bahkan yang terjadi adalah sebaliknya, Indonesia sekarang sudah jauh dari nilai-nilai Islami. Fenomena kemungkaran dan kezaliman, sudah menjadi hal yang "lumrah" bahkan "dipertontonkan" di negeri yang katanya agamis ini.

Melihat realitas seperti itu, yang menjadi latarbelakang berdirinya FPI Surabaya tidak berbeda dengan FPI di Jakarta. Sejak berdiri pada tahun 1998, FPI memang sudah getol memerangi tempat-tempat maksiat. Keberanian FPI ini dalam menggempur lokasi-lokasi kemaksiatan memang tidak main-main. Rumah-rumah pelacuran, rumah judi, termasuk kantor tempat raja media porno dunia "Playboy"di Jakarta, semua diganyang oleh laskar Islam yang satu ini. Bagi media massa, baik cetak, radio, maupun teve, tindakan FPI tersebut memang 
SYAMSUL MA'ARIF: Pemahaman Keberagamaan dan Gerakan ...

merupakan berita yang layak dijadikan tajuk utama. ${ }^{9}$ Sayangnya, menurut sejumlah anggota FPI Surabaya, ${ }^{10}$ "media-media karena banyak disusupi kelompok liberal dan kelompok penyuka kemaksiatan ini tidak bersifat objektif, buktinya yang diekspos adalah kekerasan FPI semata. Mereka tidak mencoba menampilkan sisi-sisi kebaikan FPI. Padahal sebelum kami melakukan sweeping tempat-tempat maksiat seperti tersebut, terlebih dahulu kami mencoba memberitahukan pada pihak-pihak terkait, seperti mendesak kepolisian untuk berbuat dan sebenarnya tindakan kekerasan sedapat mungkin kami hindari.". Jadi kekerasan FPI, menurut mereka merupakan jalan akhir setelah melalui beberapa prosedur. Sedangkan nama FPI sendiri adalah singkatan dari Font Pembela Islam (bahasa Arab: al-Jabhah al-Difá'iyyah alIslämiyah). Front berarti depan, sebuah nama yang mengisyaratkan para pengikutnya untuk selalu menjadi "pembela paling depan". ${ }^{11}$ FPI Surabaya sekarang, yang dideklarasikan pada tanggal 30 Juni 2008. Beralamat di Jalan Petukangan Gg 9 No. 12 Surabaya. Ketuanya bernama Habib Muhammad Mahdi bin Idrus al-Habsyi, sebagai pengganti Ali al-Habsyi yang dilengserkan oleh massa anti FPI, pasca insiden Monas.

\section{Visi dan Misi FPI}

FPI memiliki Visi untuk penegakan amar ma'ruf nahi munkar. Visi ini dianggap oleh mereka sebagai satu-satunya solusi untuk menjauhkan kezaliman dan kemungkaran. Adapun landasan dari visi ini, adalah al-Quran: "Dan hendaklah ada di antara kamu segolongan umat yang menyeru kepada kebajikan, menyuruh kepada yang ma'ruf dan mencegah dari yang munkar; merekalah orang-orang yang beruntung." (Ali Imran [3]: 104).

Tentang visi ini, Ketua FPI Surabaya menegaskan bahwa FPI selain berpegangan pada ayat di atas juga berdasarkan sebuah hadist yang berbunyi: "man ra'a minkum munkaran fa al-yugaiyyuru bi yadih...". Selanjutnya beliau menjelaskan sesungguhnya iman seseorang dibagi menjadi tiga; pertama, seseorang yang melihat kemungkaran dan berusaha mencegahnya dengan tangan mereka, inilah yang

TEOLOGIA, VOLUME 23, NOMOR 2, JULI-DESEMBER 2012 
SYAMSUL MA'ARIF: Pemahaman Keberagamaan dan Gerakan ...

disebut dengan ỉmān kāmil. Kedua, seseorang yang berusaha mencegah kemungkaran dengan lisan, inilah yang masuk kategori ïmān mutawasshit. Ketiga, seseorang yang berdiam diri ketika melihat segala bentuk kemungkaran, inilah selemah-lemahnya iman seseorang atau aḍ'a $f$ alimān. Dan FPI berusaha untuk menuju pada Iman kamil tersebut, tetapi ketika melihat setiap kezaliman dan kemungkaran, FPI mencoba mendahulukan yang mutawasshit, dengan cara memberitahukan kepada pihak-pihak yang berwenang adanya tempat-tempat maksiat dan tempattempat yang diduga melawan hukum. Lebih lanjut habib mengeluh: "sayang ini yang tidak pernah diekspos oleh media. Media telah jahat kepada FPI. Tidak menyiarkan apa adanya dan selalu mendiskriditkan kita. Mereka selalu menginformasikan hal-hal yang jelek-jelek".

Melihat visi FPI seperti itu, jelaslah bahwa mereka selalu berkeinginan untuk menegakkan amar ma'ruf nahi munkar secara käffăh (sempurna) di semua segi kehidupan manusia, dengan tujuan menciptakan umat muttaqin yang hidup dalam baldah tayyibah (negeri yang baik) dengan limpahan keberkahan dan keridhoan Allah 'Azza wa Jalla.

Sedangkan Misi FPI adalah penegakan amar ma'ruf nahi munkar untuk penerapan syariat Islam secara kăffah. Terkait dengan misi FPI ini Habib Rizieq, ${ }^{12}$ Ketua Umum FPI pernah menjelaskan bahwa misi FPI, yakni: "Posisi FPI menjadi semacam Pressure Group di Indonesia, untuk mendorong berbagai unsur pengelola negara agar berperan aktif dalam memperbaiki dan mencegah kerusakan moral dan akidah umat Islam, serta berinisiatif membangun suatu tatanan sosial, politik \& hukum yang sejalan dengan nilai-nilai syariat Islam."

\section{Gerakan FPI Surabaya}

Islam sebagai agama pamungkas dibawa oleh nabi penutup (khatam al-Anbiyā) memiliki ajaran yang komprehensif meliputi segala aspek, baik aspek sosial, ekonomi, budaya dan politik. Dan hanya satu kepentingan Islam, mensejahterakan umat manusia. Selain itu, Islam sebagai agama selalu mengajarkan kedamaian di muka bumi. Karena prinsip Islam adalah rahmatan li al-'ălamīn (rahmat bagi semesta alam). 
SYAMSUL MA'ARIF: Pemahaman Keberagamaan dan Gerakan ...

Islam bukanlah agama yang mengajarkan nilai-nilai permusuhan dan kebencian apalagi anarkhisme dan terorisme. ${ }^{13}$ Sebaliknya Islam mengajarkan nilai-nilai akhlak yang universal, nilai-nilai baku moral yang kompatibel diaplikasikan bagi seluruh umat manusia.

Prinsip toleransi Islam seperti itu, bukanlah dalam pengertian Islam sebagai sebuah agama yang tidak memiliki "prinsip". Menurut Habib Muhammad bin Mahdi, toleransi Islam sebatas "lakum dinukum waliyadin", menghormati keberadaan agama lain tetapi tidak menganggap semua agama benar. Jelas di sini mengandung pengertian bahwa Islam sebagai sebuah agama mempunyai sistem keyakinan yang wajib diikuti oleh setiap orang yang mengaku dirinya muslim. Semua yang mengaku Islam harus menyakini sesungguhnya tiada Tuhan yang berhak disembah kecuali Allah swt. dan nabi Muhammad saw. adalah utusan Allah, inilah yang terkenal dengan sebutan shahädatain, dan setiap orang yang mau masuk Islam wajib mengikrarkannya sebagai bukti kesungguhannya memeluk Islam.

Selain itu, Islam juga memiliki seperangkat aturan yang terkenal dengan sebutan syariah, yang bersumber dari al-Quran dan Hadis. Penegakan syariah ini merupakan sebuah keniscayaan, manakala setiap orang yang mengaku dirinya muslim bercita-cita menjadi seorang muslim yang kāmil (sempurna). Lagi-lagi, Habib bin Mahdi menunjukkan sebuah ayat yang berbunyi "udkhulu fi al-silmi käffah" (masuklah ke dalam agama Islam secara total) .

\section{Gerakan Sosial Melalui Penegakan Syariah dan menjaga Akidah}

Penegakan syariah dan menjaga akidah secara benar, sangat diyakini oleh kelompok FPI dapat mengantarkan kejayaan peradaban Islam. Mereka sama-sama berangkat dari keprihatinan terhadap kondisi umat saat ini, yakni keterbelakangan baik secara mental maupun ekonomi yang dialami bangsa Indonesia. Selain itu, karena adanya ketidakadilan yang dialami umat Islam dan adanya gerakan-gerakan lokal dan global yang mengancam nilai-nilai akidah (keimanan) umat Islam. Hal ini telah menggugah kesadaran mereka untuk memper-

TEOLOGIA, VOLUME 23, NOMOR 2, JULI-DESEMBER 2012 
SYAMSUL MA'ARIF: Pemahaman Keberagamaan dan Gerakan ...

juangkan martabat bangsa ini, melalui organisasi FPI dan berjuang dalam rangka amar ma'rüf nahy munkar. Upaya pembelaan umat Islam secara terorganisasi seperti FPI ini dianggap mereka sebagai sesuatu hal mendesak yang perlu dilakukan karena globalisasi yang ada saat ini sudah menjelma menjadi penjajahan gaya baru, melalui upaya-upaya pemaksaan sistem politik, budaya dan sosial ke bangsa Indonesia yang mayoritas beragama Islam.

FPI mengakui terdapat beberapa perbedaan dalam hal strategi dakwah maupun cara pandang, dengan kelompok-kelompok Islam lain, "semua perbedaan ini adalah rahmat", kata Habib. Selama ini, belum ada ormas Islam yang berkecimpung dibidang amar ma'rüf nahy munkar secara konkrit dan tegas. Gerakan FPI mengisi kekosongan wilayah perjuangan ini sebagai sebuah upaya terorganisir dan sistematis untuk memenuhi kewajiban kolektif umat Islam dalam memberantas kemungkaran.

Diterapkannya syariat Islam di Indonesia, baik secara substansial maupun formalistis, merupakan visi yang ingin dicapai FPI. Dari berbagai alternatif cara untuk mewujudkan visi tersebut, maka sekali lagi strategi yang dipilih FPI adalah melalui penegakan amar ma'rüf nahy munkar, yaitu upaya-upaya sistematis untuk mengajak umat Islam agar menjalankan perintah agamanya secara komprehensif, dan mencegah umat Islam agar tidak terjerumus pada kegiatan-kegiatan yang merusak moral dan akidah Islamnya. Melalui gerakan sadar syariah inilah, FPI yakin masyarakat Indonesia akan mencapai kesejahteraan sosial lahir batin.

Selain itu, untuk menjaga kemurnian perjuangan FPI, maka FPI tidak terlibat dalam politik praktis atau berpihak secara politik terhadap kekuasaan yang ada di Indonesia. FPI juga tidak berafiliasi atau bekerjasama secara struktural dengan organisasi manapun baik lokal maupun internasional. Motif untuk memperjuangkan syariat Islam adalah langkah yang sah, sedangkan aksi-aksi untuk memperjuangkannya diupayakan untuk tetap tunduk pada hukum yang berlaku di Indonesia.

Gerakan sosial melalui penegakan syariat dan menjaga aqidah, yang dipahami mereka bukanlah untuk membuat keonaran dan melawan 
SYAMSUL MA'ARIF: Pemahaman Keberagamaan dan Gerakan ...

hukum. Tetapi menyadarkan pada masyarakat akan arti pentingnya menerapkan hukum sesuai prinsip-prinsip Islam. "Apabila syariah di jalankan dengan sungguh-sungguh, niscaya keadilan dan kesejahteraan akan dicapai oleh bangsa ini", kata salah seorang anggota yang tidak mau menyebutkan identitasnya. Sebab menurutnya, syariah sangat memberi kepedulian yang sangat kepada masyarakat seperti; mengentaskan kemiskinan, kesehatan, pendidikan, dan memberikan keadilan kepada masyarakat sesuai peraturan perundang-undangan Islam.

\section{Gerakan Politik}

Semua gerakan dan aktivitas FPI dalam rangka menegakkan amar ma'rüf nahy munkar, bisa dibilang sebagai gerakan politik. Dimana semua ini mereka lakukan demi tercapainya kebaikan ummat dengan selalu berpegang teguh pada ajaran-ajaran Allah dan Rasulnya. Tentang persoalan ini, Habib menjelaskan, "gerakan politik yang dimaksud disini tidaklah seperti partai-partai politik, karena FPI tidak seperti PPP, PKB, dan partai lainya. Sebab, FPI bukan partai politik dan perjuanganya bersifat murni dan atas dorongan ajaran agama Islam semata".

Gerakan politik FPI terbatas pada hal-hal yang berkaitan erat dengan urusan masyarakat sesuai dengan prinsip-prinsip hukum dan aqidah Islam. Sesuatu yang bertentangan dengan Syari'ah dan Aqidah Islam akan menjadi tanggungjawab FPI untuk meluruskanya, meskipun hal ini harus dibayar dengan sangat mahal. Asal masyarakat terbebas dari pemikiran-pemikiran sesat, terhindar dari kekufuran dan akidah yang rusak.

Semua gerakan politik yang pernah dilakukan FPI, baik yang menyangkut perkara diluar atau di dalam pemerintahan-seperti penggerebekan tempat-tempat maksiat, menentang RUU pornografi, menentang imperialisme Barat serta berusaha membebaskan ummat dari cengkeraman dan pengaruhnya - adalah dalam rangka merealisasikan visi dan misi politik FPI. Khusus tentang imperialisme Amerika dan Barat, terdapat kesan FPI memiliki ikatan kebersamaan yang kuat yang dibangun dalam ikatan kesamaan persamaan nasib dan menunjukkan perasaan telah menjadi korban sejarah. Semua ini terkadang tereks-

TEOLOGIA, VOLUME 23, NOMOR 2, JULI-DeSEMBER 2012 
SYAMSUL MA'ARIF: Pemahaman Keberagamaan dan Gerakan ...

presikan dalam bentuk gerakan-gerakan anti-Barat atau anti-Amerika. Dan kita pun sering melihat kalau mereka selalu melakukan sweeping anti-Amerika dan Israel, termasuk berunjuk rasa di depan kedutaan AS, Australia, dan Inggris.

Sedangkan dengan melihat realitas sistem hukum dan politik di Indonesia yang cenderung sekuler, menurut FPI, hal ini secara nyata telah membuat sebagian dari nilai-nilai ajaran Islam tidak terakomodasi dalam perangkat hukum negara. Dalam ruang yang kurang tersentuh pasal-pasal hukum inilah FPI melakukan berbagai pendekatan solusi agar nilai-nilai ajaran Islam dapat diterapkan secara lebih komprehensif.

Penyakit masyarakat yang bersifat struktural, misalnya industri pornografi atau perjudian, harus dihadapi secara tegas baik dengan pendekatan hukum maupun tekanan-tekanan politis. Pembiaran terhadap kejahatan sosial semacam ini berpotensi membuahkan berbagai bentuk penyakit masyarakat yang pada akhirnya akan merusak berbagai sendi nilai-nilai moral dan bahkan akidah umat Islam. Segala bentuk kejahatan sosial yang bersifat struktural adalah ruang gerak yang menjadi prioritas FPI untuk dihadapi secara struktural pula.

Jadi, gerakan politik FPI bisa dikatakan sebagai bentuk kritik dan protes terhadap negara yang dianggap tidak becus mengurusi persoalan ummat. Tentang bentuk kekecewaan seperti ini, bahkan Ketua FPI Surabaya berkata: "kalau sudah tidak sanggup mengurus negara, serahkan kepada kita. Biar kita-kita yang mengaturnya".

Wajar kalau FPI menuntut seperti itu, karena menurut anggapan mereka, negara dengan mayoritas muslim, maka sudah sewajarnya posisi tawar umat Islam lebih besar. Posisi tawar yang besar ini diterjemahkan dalam bentuk hak kolektif umat Islam yang lebih signifikan, antara lain hak umat Islam untuk memiliki lingkungan sosial yang bersih dari berbagai 'penyakit masyarakat', seperti bersih dari pornografi, bersih dari perjudian, bersih dari narkoba dan lain-lain. Adalah wajar pula sebagai mayoritas bila umat Islam mewujudkan hak kolektifnya dengan menuntut pemerintah setempat untuk mengadopsi sebagian dari nilai-nilai ajaran Islam (syariat), tentunya nilai-nilai moral 
SYAMSUL MA'ARIF: Pemahaman Keberagamaan dan Gerakan ...

yang bersifat universal dan tidak bertentangan dengan keyakinan umat beragama lainnya.

\section{Gerakan Dakwah}

"Tiada hari tanpa dakwah", begitulah kira-kira hasil observasi dilapangan selama peneliti mengadakan penelitian FPI Surabaya. Karena setiap bentuk interaksi habib - baik yang formal pengajian maupun tidak - dengan para jamaah dan tamunya selalu diselingi dengan ajakan kepada jalan yang haq dan diridhoi Allah dan Rasul-Nya. Ajakan menuju jalan Allah, menurut habib, harus senantiasa dilaksanakan sebagai bentuk ajaran al-Quran: "watāwa șau bi al-ḥaq watāwa sau bi al-sabr'.

Senada dengan Habib, salah seorang anggota FPI mengatakan dengan menggunakan bahasa Arab: "qul al-haqqa walau kāna murra” (katakanlah yang benar meskipun hal itu menyakitkan). Sebuah prinsipprinsip yang memberikan arti pentingnya sebuah ajaran dakwah bagi kehidupan seorang muslim. Resiko dakwah tidak menjadi hambatan bagi mereka. Apalagi harus mengorbankan sebuah nyawa. Sebab, "mati dalam keadaan berdakwah adalah mati syahid", kata seorang anggota FPI Surabaya.

Pada setiap malam Jumat, FPI Surabaya selalu mengadakan Istighātsah dan Mujāhadah. Pada saat peneliti mengikuti acara tersebut, peneliti benar-benar mengerti bagaimana proses dakwah dan berdo'a ala FPI Surabaya dilaksanakan. Disinilah tampak bagaimana kharisma habib, karena setiap santri yang mengikuti acara tersebut pasti berjabat tangan secara "berebutan" sambil menciumnya. Setelah itu, mujahadah dimulai dengan membaca serentetan hadrah kepada Rasulullah, sahabat dan salaf al-sālị serta para leluhur. Kemudian diikuti dengan membaca tahlil tahmid, dan Ayat Kursi. Setelah selesai mereka meneruskan dengan Shalat Hajat dan Sujud Syukur. Sujud syukur, kira-kira dilakukan sekitar seperempat jam. ${ }^{14}$ Sebelum melakukan sujud syukur, Habib berpesan kepada para jamaah agar berdoa sesuai dengan kebutuhan masing-masing dan yang terpenting sesuatu yang menjadi visi dan misi perjuangan FPI terkabul dan diridai Allah swt.

TEOLOGIA, VOLUME 23, NOMOR 2, JULI-DESEMBER 2012 
SYAMSUL MA'ARIF: Pemahaman Keberagamaan dan Gerakan ...

Setelah acara istighasah selesai seperti biasanya Habib memberikan siraman rohani. Intinya dakwah yang senantiasa dilakukan FPI adalah mendorong para jamaah dan kaum muslimin melakukan kebaikan dan mentaati petunjuk Allah, menyuruh mereka melakukan kebajikan dan mencegah mereka dari kemungkaran, agar meraih kebahagiaan di dunia dan akhirat.

Memang telah terjadi beberapa perbedaan pengertian tentang dakwah yang dilakukan oleh umat Islam. Adakalanya dakwah didefinisikan mereka secara kreatif, inovatif dan kontektual. Biasanya definisi dakwah seperti ini sering menggunakan cara-cara yang "santun". Tetapi ada juga yang mengartikan dakwah secara normatiftekstualis, biasanya sering menggunakan teguran bahkan "kekerasan". Dakwah dalam perspektif FPI, menurut pengamatan peneliti, nampaknya mengambil suatu prinsip ajaran dakwah yang didefinisikan oleh ulama-ulama seperti Sayyid Quṭb dalam kitab Tafsìr fí Zilāl alQur'ān, ${ }^{15}$ yaitu mengajak orang lain untuk menyakini dan mengamalkan akidah dan syariat Islam yang telah ditetapkan Allah SWT., serta seperti pandangan Ibnu Taimiyah dalam Majmū' al-Fatāwa, ${ }^{16}$ yang mengartikan dakwah sebagai suatu proses usaha untuk mengajak agar orang beriman kepada Allah, percaya terhadap apa yang telah diberitakan oleh Rasul dan taat terhadap apa yang telah diperintahkan yang meliputi dua kalimah syahadat, menegakkan shalat, menunaikan zakat, puasa bulan ramadhan, haji, iman kepada malaikat, kitab-kitabNya, hari kebangkitan, qadha dan qadar.

Berdasarkan pengertian dakwah seperti tersebut, FPI menganggap munculnya aliran-aliran seperti Ahmadiyah, Lia Eden, ${ }^{17}$ SEPILIS, dan lain adalah telah keluar dari kontek Islam. Sehingga mereka wajib "diperangi". 18 Dalam pandangan mereka, tindakan umat Islam yang tegas dengan menutup, menyerang atau merubuhkan markas dan simbol kesesatan, harus dilihat sebagai reaksi pembelaan dari suatu aksi brutal yang menyerang aqidah mereka. Tindakan mereka bukanlah merupakan aksi anarkis melainkan sebuah tuntutan dakwah Islamiyah. Dan terdapat sejumlah ayat al-Quran menjadi Hujjah mereka, seperti QS. al-Taubah ayat 73 dan 123, serta QS. al-Tahrim ayat 9, begitu pula QS. al-Fath 
SYAMSUL MA'ARIF: Pemahaman Keberagamaan dan Gerakan ...

ayat 29, yang semuanya berintikan sikap tegas terhadap kekafiran, kesesatan dan kemunafikan.

\section{E. Beberapa Pemahaman Keagamaan Kelompok FPI Surabaya}

\section{Jihad}

Entah kenapa ketika sedang membicarakan persoalan Jihad, kelompok FPI memiliki semangat tersendiri untuk selalu berusaha memberikan penjelasan dalam prespektif mereka, tentu saja sebuah pemahaman yang sudah mendarah daging dan seperti telah menjadi "kesepakatan bersama" dalam kelompok FPI secara keseluruhan di Indonesia. Tidak ada satupun perbedaan pandangan antara habib dan para jama'ahnya tentang persolan Jihad ini.

Jihad oleh mereka lebih dipandang sebagai panggilan jiwa untuk selalu membela Islam. Bukankah Jihad secara lughowi berarti "bersungguh-sungguh dan berupaya keras"?, kata seorang anggota FPI ketika memberikan penjelasan kepada peneliti. Bahkan bisa jadi jihad ini sampai kepada qitāl fì sabìl Allăh. Habib kemudian memberikan penjelasan. Jihad yang berarti "perang suci" ini, kalau secara nyatanyata kita diganggu oleh kelompok lain. Diganggu ini pengertianya banyak, seperti; agama kita diserang, diejek dan dinodai. Atau mungkin kita tidak diganggu tetapi, Allah dan nabi kita diganggu. Maka kita sebagai umat Islam memiliki kewajiban bersama untuk menyerukan kata "jihad". Lagi-lagi, beliau memberikan beberapa contoh yang masuk dalam katagori pengganggu agama Islam adalah Ahmadiyah, Lia Eden, dan SEPILIS.

Untuk mengobarkan semangat jihad kepada para anggotanya, FPI mempunyai mars yang berhubungan dengan anjuran jihad ini. Sesekali mereka membaca secara bersama-sama mars ini, untuk selalu membangkitkan dan mengingatkan prinsip berjihad untuk selalu membela agama Allah SWT. Berikut mars FPI ${ }^{19}$ yang berkaitan erat dengan anjuran jihad:

TEOLOGIA, VOLUME 23, NOMOR 2, JULI-DESEMBER 2012 
SYAMSUL MA'ARIF: Pemahaman Keberagamaan dan Gerakan ...

\author{
MARS FPI \\ Mari Kita Jihad \\ Allahu Akbar, Allahu Akbar, Allahu Akbar, Allahu Akbar 2 X \\ Allah Tuhan kami, Dia tujuan kami \\ Muhammad Sang Rasulullah, Dia Teladan kami \\ Al-Qur'an pedoman kami \\ Jihad jalan juang kami \\ Mati Syahid harapan kami \\ Allahu Akbar, Allahu Akbar, Allahu Akbar, Allahu Akbar 2 X \\ Ayo kita jihad Ayo kita jihad \\ Membela Islam dan muslimin \\ Hidup mulia atau mati syahid $4 X$ \\ Allahu Akbar, Allahu Akbar, Allahu Akbar, Allahu Akbar $2 X$
}

Tentang hukum jihad secara jelas, FPI Surabaya sangat terpengaruh dengan bacaan mereka dalam memahami konsep jihad yang terdapat dalam ayat-ayat al-Quran ${ }^{20}$ seperti: Orang-orang yang beriman dan berhijrah serta berjihad di jalan Allah dengan harta dan jiwa mereka (mereka mendapatkan) derajat yang paling mulia di sisi Allah dan menrekalah orang-orang yang berbahagia.Allah meberi kabar gembira bahwa mereka mendapat rahmat dari pada Nya, mendapat keridhoan dan syurga yang di dalamnya penuh dengan kenikmatan yang kekal abadi, sesungguhnya Allah memiliki pahala yang besar (QS. al-Taubah [9]: 20-22).

Selain itu, mereka juga sangat memegang erat pendapat para ulama fikih, terutama sekali yang bermazhab sunni. Hal ini nampak, pada kitab-kitab fikih yang sering menjadi pijakan dan pengambilan dasar hukum seperti Fath al-Mu'in, Fath al-Qarīib, dan lain-lain. Sedangkan ketika penelitian ini dilakukan, mereka sedang mengkaji sebuah kitab Kifäyah al-Akhyār. "Pengajian kitab-kitab ini dilakukan setiap hari minggu pagi", kata salah seorang jama' ah. ${ }^{21}$

Berdasarkan pelacakan dari kitab-kitab yang menjadi referensi mereka tersebut menjadi semakin jelas, bahwa hukum jihad atau perintah melakukan qitāl dapat diklasifikasikan sebagai berikut: pada masa Rasulullah setelah hijrah adalah fardu kifãyah. Sedangkan setelah Rasul wafat, maka perintah jihad itu dibagi menjadi dua. Pertama, jihad 
SYAMSUL MA'ARIF: Pemahaman Keberagamaan dan Gerakan ...

ke negeri kafir, maka jihad tersebut adalah farḍ kifayah bagi kaum muslim setiap tahun. Apabila sudah ada yang melakukan maka gugurlah dosa itu bagi yang lainya. Kedua, jika orang-orang kafir menyerbu salah satu negeri kaum muslim, atau menduduki wilayah yang dekat dengan negeri muslim, maka jihad itu menjadi fardu 'ain bagi kaum muslimin. Dan wajib bagi penduduk negeri muslim untuk melawan serbuan orangorang kafir itu dengan segala upaya. ${ }^{22}$

Seandainya mereka harus kalah dan berkorban nyawa demi membela agama Allah, mereka tidak gentar. "Sebab mati syahid adalah cita-cita kami", kata salah seorang anggota FPI. Mereka meyakini, pengikut FPI yang tewas dalam memberantas kemungkaran mereka anggap telah mati syahid. Dan orang yang mati dalam keadaan membela agama Allah dan Rasulnya, mereka beranggapan akan langsung masuk surga. Oleh sebab itu, salah seorang anggota FPI berseru: "mari segera kita menyerukan berjihad fi sabill Alläh. Siapa lagi kalau bukan kita, sebagai umat Islam yang memberantas segala bentuk kemungkaran yang jelas-jelas sedang merajalela di negara kita dan berusaha dengan segala daya untuk melenyapkan segala bentuk pemikiran dan akidah yang melenceng dan menghina Islam".

Karena didukung oleh hukum yang jelas tentang Jihad dalam Islam. FPI nampak memiliki sebuah "keyakinan" bahwa Jihad melawan kekafiran dan orang-orang kafir pada saat sekarang adalah tugas suci. Apalagi, "mereka" secara jelas telah dianggap oleh FPI mezalimi dan menghina Islam. Oleh sebab itu, semua mukmin sejati yang terdiri dari semua laki-laki muslim, dewasa, sehat jasmani diwajibkan ikut ambil bagian dalam memerangi setiap bentuk kekafiran dimuka bumi ini.

Sebagaimana terungkap dalam pedoman perjuangan FPI di atas, bahwa "Jihad adalah jalan kami (jihad tenaga, jihad lisan, jihad hati, jihad ibadah, jihad ilmu, jihad harta, jihad nafkah, dsbnya)". Maka terdapat beberapa katagori jihad yang diyakini FPI, yaitu adakalanya jihad dengan menggunakan tenaga, lisan, ibadah, ilmu, harta, nafkah, $\mathrm{dll}^{23}$ Semua orang muslim dengan segala kapasitas yang dimiliki wajib menunaikan ajaran jihad ini. Tentu saja, kapan dimulai dan berakhirnya sebuah jihad seperti:memerangi segala "kemaksiatan". Harus ditentukan 
SYAMSUL MA'ARIF: Pemahaman Keberagamaan dan Gerakan ...

oleh seseorang imam atau pemimpin keagamaan yang dapat memberi komando. Semua ini dengan suatu tujuan agar jihad dapat dilakukan secara kolektif dan efektif bisa mencapai sasaran yang optimal.

Sedangkan sasaran jihad mereka adalah setiap "bentuk kemaksiatan, kekafiran dan kezaliman" ${ }^{24}$ Wajar karena menganggap mereka sebagai pembela Islam sejati, yang demi Islam dan dorongan jihad itulah mereka melakukan serangkaian penutupan terhadap tempat-tempat maksiat dan penuntutan terhadap pemerintah untuk membubarkan kelompok-kelompok yang dianggap sesat, seperti Ahmadiyah, dkk. Meskipun tindakan seperti ini berakhir dengan predikat yang kurang positif $^{25}$ yang dicitrakan oleh masyarakat Indonesia (berkat media tentu saja) - sebagai sebuah organisasi yang suka kekerasan dan menciderai pluralitas masyarakat Indonesia yang memiliki keragaman agama, budaya, dan etnik.

\section{Khilafah}

Telah terjadi perbedaan yang sangat menonjol di kalangan umat Islam terhadap implementasi penegakan syari'ah dan pendirian negara Islam atau sering disebut dengan daulah Islämiyah dengan sistem khilafah. Diantara mereka terdapat kelompok yang secara terang-terangan menyebutkan aktivitas dan gerakannya untuk membentuk sistem pemerintahan dengan sistem khilafah ini, ${ }^{26}$ namun tak sedikit dari mereka yang justru menolak ide pendirian Daulah Islämiyah.

Dengan beragam dalil dan tafsir mereka gunakan sebagai landasan untuk memperkuat pemikiran masing-masing. Sedangkan FPI adalah salah satu kelompok keagamaan yang cukup "menarik" dalam merepon persoalan khilafah ini, kerena meskipun syariah Islamiyah merupakan "harga mati" yang perlu diperjuangkan, namun mereka tidak secara terang-terangan berkeinginan

Hukum pendirian negara atau pemerintahan khilafah menurut pandangan FPI yang menganut Aswaja adalah fardu kifáyah. Sikap politik sunni ini, menurut Aqil Siradj ${ }^{24}$ adalah suatu sikap moderat yang mencoba menjembatani dua pandangan kelompok ekstrim, yakni antara kaum Syi'ah yang menjadikan keberadaan pemerintahan merupakan 
SYAMSUL MA'ARIF: Pemahaman Keberagamaan dan Gerakan ...

sebagai rukun imam dan kaum khawarij yang memperbolehkan adanya komunitas pemerintahan vakum.

Karenanya negara Islam selamanya tidak diketemukan dalam kosa kata perpolitikan kaum sunni yang dianut mayoritas kaum muslim di dunia, termasuk Indonesia. Dalam prespektif mereka, Nabi saw serta para khulafá' Rāsyidin tidak pernah mengerek bendera Islam sebagai simbul negara, apalagi penguasa Dinasti umayyah, Abasyiah hingga Turki Usmani yang membangun sistem monarchi absolut. Bagi sunni sepanjang suatu negara — dengan bentuk apapun-menegakkan prinsipperinsip syariat Islam; bersikap adil (al'adl), persamaan derajat dalam hukum (musāwah), menjunjung tinggi, musyawarah (al-shüră) serta menjamin ditegakkanya lima prinsip universal (kulliyat al-khams) berarti negara tersebut tercakup dalam kategori 'negara islami'.

\section{Islam Kāffah}

Sesuai dengan namanya yang tidak terkait dengan nama orang, suku, atau wilayah tertentu, maka Islam adalah agama yang tidak diperuntukkan bagi suku tertentu. Bahwa Islam adalah agama untuk semua orang di seluruh dunia dan di sepanjang zaman. Dengan begitu agama Islam disebut sebagai agama universal, sebab tidak terkait oleh waktu dan tempat.

Dan untuk mengetahui lebih jelasnya lagi tentang Islam, maka ada dua sumber pokok ajaran Islam yang perlu diketahui, yaitu al-Quran dan al-Sunnah. Yang dimaksud dengan al-Quran sendiri adalah kumpulan wahyu Tuhan yang diturunkan oleh Tuhan kepada Nabi Muhammad saw. secara berangsur sesuai dengan kebutuhan. Sedangkan yang dimaksud dengan al-Sunnah sendiri adalah segala perkataan, perbuatan dan sikap nabi ketika melihat atau mengetahui suatu kejadian.

Islam sebagai wahyu yang memberikan bimbingan kepada manusia mengenai semua aspek hidup dan kehidupannya, dapat diibaratkan seperti jalan raya yang lurus dan mendaki, memberi peluang kepada manusia yang melaluinya sampai ke tempat ynag dituju, tempat tertinggi dan mulia. Jalan raya itu lempang dan lebar, kiri dan kanannya berpagar al-Quran dan al-Hadis. Pada jalan itu terdapat rambu-rambu, yang tanda-tanda serta jalur-jalur sebanyak aspek kehidupan manusia.

TEOLOGIA, VOLUME 23, NOMOR 2, JULI-DESEMBER 2012 
SYAMSUL MA'ARIF: Pemahaman Keberagamaan dan Gerakan ...

Siapa saja yng memasuki gerbang jalan raya itu baik karena keturunan maupun karena mengucapkan dua kalimat syahadat, wajib memperhatikan rambu-rambu, tanda-tanda dan berjalan melalui jalurjalur yang telah ada. Berpikir, bersikap dan berbuat sesuai dengan ajaran Islam, tidak menabrak pagar (al-Quran dan al-Hadis) itu apalagi keluar dari keduanya. Apabila seseorang sudah berusaha mengamalkan semua ini, maka dia sudah berusaha menjadi muslim käffah.

Sebagai agama wahyu yang terakhir, agama Islam merupakan satu sistem akidah dan syariah serta akhlak yang mengatur hidup dan kehidupan manusia dalam berbagai hubungan. Agama Islam tidak hanya mengatur hubungan manusia dengan manusia dalam masyarakat termasuk diri manusia itu sendiri tetapi juga dengan alam sekitarnya yang kini terkenal dengan istilah lingkungan hidup. ${ }^{25}$

Karena Islam itu berarti kepatuhan kepada kehendak-kehendak Allah dan taat hukum-hukum-Nya, dan karena itu adalah inti dari setiap pesan dan ajaran yang disampaikan Allah melalui utusan-utusan-Nya, maka seorang muslim selalu menerima seluruh nabi sebagaiman mereka menerim Nabi Muhammad saw. tanpa adanya rasa diskriminasi. Dia percaya bahwa seluruh Rasul yang telah diutus oleh Allah, dan para pengikutnya adalah muslim seperti mereka juga, dan bahwa agama mereka juga Islam, satu-satunya agama yang benar-benar universal dari Allah (QS. al-Baqarah [2]: 128-140; Ali 'Imrān [3]: 78-85; al-Isrā [17]: 42-44; Luqmān [31]: 22; al-Shūrā [42]: 13).

Nama yang sebenarnya agama ini adalah Islam dan pengikutnya disebut "Muslim". Dalam hal ini Islam itu berarti kepatuhan pada kehendak Allah dan tunduk pada hukum-hukum-Nya. Dan kehendak Allah telah digarisbawahkan oleh al-Quran sebagai wahyu yang agung, dan hukum-hukumnya merupakan hukum-hukum yang baik dan teratur. Demikianlah sehubungan dengan al-Quran telah menyebutkan bahwa Ibrahim dan nabi-nabi yang diyakini umat Islam, dan selanjutnya menyatakan bahwa agama mereka ada di bawah satu nama yaitu Islam.

\section{Sharī'ah Islāmiyah}

Sebagaimana telah terungkap pada pembahasan tentang visi dan misi FPI diatas, sesungguhnya persoalan Shari' ah Islämiyah merupakan 
SYAMSUL MA'ARIF: Pemahaman Keberagamaan dan Gerakan ...

"harga mati" yang akan selalu diwujudkan dan diperjuangkan pelaksanaannya di Indonesia. FPI memandang Syariah adalah satu-satunya nizām al-Isläm ${ }^{29}$ yang di dalamnya terkandung segala perintah yang telah diperintahkan oleh Allah dan larangan-larangan yang telah dilarang oleh Allah. Jadi kata shari' ah digunakan untuk pengertian hukumhukum Allah yang diturunkan untuk manusia. Shari' ah merupakan salah satu perkara yang sangat penting dalam Islam. Dengan syariat dapat diwujudkan kemaslahatan umat baik di dunia maupun di akhirat. Sebab dalam keyakinan mereka, syariat atau ajaran Islam bukan hanya mengenai satu segi saja dari kehidupan manusia melainkan meliputi seluruh aspek kehidupan, seperti yang berkenaan dengan aspek keimanan, peribadatan, akhlak sejarah, kebudayaan dan ilmu pengetahuan. Hal ini terungkap dari pernyataan seorang aktivis FPI ketika diwawancarai:

"Seandainya saja umat Islam Indonesia memahami fungsi dan prinsip syariah bagi kehidupan. Niscaya mereka akan senantiasa terhindar dari segala bentuk petaka atau multi krisis seperti yang telah dialaminya. Dan pada dasarnya semua malapetaka yang sedang melanda bangsa kita ini, bersumber dari kezaliman dan kemungkaran."

Tetapi yang paling mengherankan, masih menurut anggota FPI, "bangsa yang katanya mayoritas beragama Islam ini justru sangat alergi dengan penerapan syariat. Mereka dari rakyat hingga pejabatnya, seolah-olah mempersulit dan memprotes setiap bentuk undang-undang yang bersumber dari al-Quran dan hadis". Ali Murtafiq, selaku intelijen FPI Surabaya lalu berdoa: "Semoga besok dalam pemilihan umum kita dapat memilih pemimpim-pemimpin yang baik, mengerti akan hukumhukum yang bersumber dari ajaran Islam".

Menjalankan shari' ah Islāmiyah yang dimaksud FPI, sebagaimana penjelasan Habib adalah "menjalankan prinsip-prinsip hukum Islam secara menyeluruh tidak sepotong-potong". Tetapi aneh, habib memberi contoh tentang pelaksanaan syariah di Indonesia seperti di Aceh missalnya, terkesan sebagai ajang coba-coba. "Masak memberi sanksi bagi para perampok dan pendosa, dengan dicambuk dan cambuknya kecil lagi. Kapan jeranya...! habib bergumam. Dan sebagaimana pandangan

TEOLOGIA, VOLUME 23, NOMOR 2, JULI-DESEMBER 2012 
SYAMSUL MA'ARIF: Pemahaman Keberagamaan dan Gerakan ...

umum dikalangan umat Islam, bahwa syariah Islam, memang memiliki ruang lingkup antara lain; keimanan atau akidah, moral atau akhlak, sanksi dan perwujudan iman. Meminjam ungkapan Sayyid Abu Bakar, dalam kitab Kifâah al-Atqiyā' wa al-Minhāj al-Shifầ: "Sharī'ah diumpamakan perahu, sedangkan tariqqah seperti lautan dan hakikat adalah mutiara yang mahal. Dengan demikian, shari' $a h$ adalah menjalankan agama Allah dan menegakkan perintah-Nya serta meninggalkan laranga-Nya. ${ }^{30}$ Semua ini oleh FPI, harus dijalankan secara menyeluruh dan terkait satu sama lainya.

Melihat semua pandangan FPI tentang shari' ah Islam, bisa disimpulkan bahwa shari'ah adalah "cita-cita" dan diyakini mereka sebagai solusi keluar dari semua bentuk kemungkaran di Indonesia. Kembali kepada syariah Islam, ditengah-tengah mengguritanya setiap bentuk kezaliman, sementara pemerintah dalam hal ini pihak penegak hukum, dianggap tidak berdaya menghentikannya - adalah sebuah kewajiban. Maka, sebagai upaya merealisasikan semua bentuk ketaatan terhadap syari'ah dan berusaha menjadi muttaqin, mereka melakukan aksi-aksi seperti: penutupan, sweeping dan pengrusakan tempat-tempat maksiat. Di sini, kalau kita analisis secara medalam, sebenarnya telah terjadi sebuah dialektika antara apa yang disebut "realitas" dengan suatu prinsip ajaran yang diyakini kebenarannya oleh FPI.

Salah satu sisi, mereka dituntut menjadi warga yang baik karena pada kenyataanya mereka hidup di negara yang tidak menganut sistem syariat. Di sisi lain, mereka merasa memiliki tanggung jawab untuk amar ma'rüf nahy munkar, menegakkan syariah seperti yang diyakini kebenarannya. Sementara itu, FPI juga memiliki semacam idiologi bahwa, ketaatan dan kepatuhan rakyat kepada pemerintah sebagai konsekuensi bernegara adalah wajib selama pemimpinnya tidak menyimpang dari ketaatan syariat Allah dan Rasulnya. ${ }^{31}$ Padahal menurut kayakinan mereka, pemerintah sudah banyak melanggar ketentua-ketentuan syari'ah. Maka, segala macam "protes" kepada pemerintah adalah sah-sah saja.

Dalam konteks ini, nampaknya kebingungan klasifikasi yang diberikan oleh Andri Rosadi terkait mazhab dan idiologi FPI terjawab 
SYAMSUL MA'ARIF: Pemahaman Keberagamaan dan Gerakan ...

sudah. Karena memang, FPI sebagaimana penelitianya, dicirikan sebagai sebuah "organisasi Islam yang beraliran Ahlu al-Sunnah wa alJama'’ah dan bermazhab Shafi'i. Tetapi, pertanyaan Rosadi kenapa FPI sering memprotes pemerintah? Sementara aliran sunni melarang adanya gerakan protes terhadap penguasa, apa pun kondisinya, selama penguasa masih mendirikan shalat". Padahal jelas-jelas, mereka memang beraliran idiologi sunni, meskipun terkadang bersifat radikal dan fundamental. Sebab, menurut anggapan mereka pada saat tertentu mereka membutuhkan "kekerasan", dalam arti sikap radikal dengan aksi sebagi shock therapy, ${ }^{32}$ bagi penguasa yang lalai dan para pengusaha tempat hiburan atau para penganjur kesesatan beragama yang masuk golongan SEPILIS. Bahkan Habib Rizieq dalam buku terbarunya yang berjudul "Pledoi Ketua Umum FPI Habib Muhammad Rizieq Syihab"33 telah menjelaskan bahwa kekerasan pada saat tertentu sangat diperlukan. Menurutnya terdapat dua macam kekerasan; kekerasan yang terpuji dan kekerasan tercela. Kekerasan terpuji adalah sebagai cerminan tegas sikap dan tegar prinsip, sedangkan kekerasan tercela adalah cerminan sikap kasar dan bengis alias ANARKISME. Kekerasan yang FPI lakukan adalah masuk katagori terpuji sebab yang dilakukan dalam rangka sikap ketegasan dalam melihat setiap bentuk KESESATAN.

Lebih lanjut dalam buku tersebut Habib berkata: "Islam adalah agama perdamaian, tapi bukan berarti tidak tegas terhadap kesesatan, dan bukan pula berarti damai dengan Penistaan Agama. Karena tidak tegas terhadap KESESATAN adalah kefasikan. Damai dengan PENISTAAN AGAMA adalah kemunafikan".

Meskipun demikian, FPI seharusnya melakukan intropeksi dengan segala bentuk "kekerasan" yang selama ini mereka lakukan. Sebab watak kekerasan dengan dalih menegakkan amar ma'rüf nahy munkar, pada tingkat tertentu bisa memunculkan konflik horizontal. Yang paling menyedihkan adalah sesama umat Islam, yang sama-sama ingin menegakkan syariah Islamiyah - meskipun dengan prinsip dan pandangan yang berbeda. Apalagi, kekerasan FPI yang tidak diimbangi dengan perhitungan yang matang dan analisis jauh ke depan. Maka

TEOLOGIA, VOLUME 23, NOMOR 2, JULI-DESEMBER 2012 
SYAMSUL MA'ARIF: Pemahaman Keberagamaan dan Gerakan ...

sikap politik yang keras seperti itu akan menghasilkan risiko besar, tentu saja.

\section{F. Penutup}

FPI ketika dilihat dari tatanan ideologis-fundamentalis menyerukan rekonstruksi sosial dan moralitas dengan berdasarkan pada seruan kembali kepada al-Quran dan hadis. Mereka ingin menemukan kembali ajaran Islam tanpa ada deviasi historis, dan distorsi yang berasal dari nalar, sambil menyingkirkan segala tradisi budaya juga adat istiadat lokal yang menempel diajaran Islam.

FPI melalui gerakan-gerakannya berusaha menyerukan kembali kepada ajaran Islam yang murni dan menjaga akidah kaum muslimin dari setiap pemikiran yang sesat. Semua itu terekam dan tergambar jelas dalam visi misi FPI, sebagai bentuk perintah amar ma'rüf nahy munkar. Maka setiap bentuk kesesatan, penyimpangan dan penodaan agama, seperti yang dilakukan Ahmadiyah dan kelompok SEPILIS (Sekulerisme, Pluralisme dan Liberalisme) oleh FPI dianggap sebagai musuh yang harus diperangi.

Bagi FPI, Islam adalah akidah, syariat, dan akhlak. Ketiganya menjadi satu kesatuan yang tak terpisahkan, satu sama lainya saling terkait dan saling menyempurnakan. Semua umat Islam wajib memiliki ketiga-ketiganya sebagai bentuk implementasi Muslim Käffah. Dan harus tertanam dalam hatinya untuk senantiasa berjuang membela kemurnian Islam. Perjuangan menjaga kemurnian dan kemuliaan Islam, diyakini FPI sebagai jihad. Berdasarkan prinsip inilah, setiap bentuk "kekerasan" yang selama ini mereka lakukan tidak bisa disamakan dengan sikap Anarkisme, tetapi sebagai bentuk sikap ketegasan dalam memandang setiap "kesesatan".

Sikap-sikap FPI seperti tersebut bisa dikatakan sebagai bentuk ekspresi terdalam dari seorang muslim dalam mengartikulasikan ajaranajaran agama yang dipeluknya. Atau sebagai bentuk sikap "kesalehan" dalam memandang setiap keyakinan yang berbeda dengan keyakinan yang diyakininya. Meskipun pada realitas social-empiricnya, sering berhadapan dengan pandangan yang berbeda dan sering berending 
SYAMSUL MA'ARIF: Pemahaman Keberagamaan dan Gerakan ...

dengan permusuhan dan kekerasan. Seharusnya, semua pihak harus mengedepankan sikap saling menghargai dan mencari titik temu diantara mereka demi perdamaian abadi dinegeri tercinta ini. []

\section{Catatan Akhir}

${ }^{1}$ Terdapat sejumlah nilai, norma dan etika yang merupakan ruh demokrasi, tanpa ini semua demokrasi menjadi semu. Mayo dalam bukunya An Introduction to Democratic Theory menyebutkan nilai demokrasi sebagi berikut: (1). Menyelesaikan perselisihan dengan damai dan secara sukarela; (2). Menjamin terselenggaranya perubahan secara damai dalam suatu masyarakat yang sedang berubah; (3). Menyelenggarakan pergantian pimpinan secara teratur; (4). Membatasi pemakaian kekerasan; (5). Mengakui serta mengganggap wajar adanya keberbagian dalam masyarakat; (6). Menjamin tegaknya keadilan; dan (7) adanya nilai-nilai yang dihasilkan oleh kelemahan-kelemahan sistem yang lain. Sementara Cunningham memberikan ciri-ciri demokrasi sbb; pemeliharaan situasi yang damai, adanya kepemimpinan yang baik dan berpengaruh; wisdom; stabiltas; legitimasi; kesejahteraan; keadilan sosial; persamaan; dan kemerdekaan yang positif. Lih. F. Cunningham, Theories of Democracy: A Critical Introduction, New York: Routledge, 2002, h. 149-162.

${ }^{2}$ Sebagaimana pelacakan dari beberapa referensi, fundamentalis adalah termasuk dalam gerakan revivalis dan ide dasarnya adalah kembali ke ajaran Islam yang benar sebagaimana yang dipraktekkan oleh kaum salaf al-săhihh. Kekalahan Islam dari Barat dipandang sebagai akibat dari ditinggalkannya ajaran Islam yang benar. Agar kembali mencapai kejayaannya, umat Islam harus kembali kepada ajaran yang telah mampu mengangkat umat Islam mencapai kejayaannya pada masa lampau. Untuk persoalan seperti ini bisa dilihat dalam James P. Piscatori, Islam in a World of Nation-State, Cambridge, New York: Cambridge Univercity Press, 1988, h. 119-120.

${ }^{3}$ Untuk pengelompokan gerakan Islam menjadi dua kelompok seperti ini bisa dilihat dalam Muhsin Jamil, Membongkar Mitos Menegakkan Nalar: Pergulatan Islam Liberal versus Islam Literal, Yogyakarta:Pustaka Pelajar, 2005.

${ }^{4}$ Charles Kurzman, Wacana Islam Liberal: Pemikiran Islam Kontemporer tentang Isu-isu Global, Jakarta: Paramadina, 2001, h. xliv.

${ }^{5}$ Coba bandingkan analisis munculnya ormas-ormas pasca reformasi oleh Ahmad Gauf AF, "Islam Progresif: Wacana Pasca Arus Utama", dalam Jurnal Taswirul Afkar, edisi No. 22 Tahun 2007.

${ }^{6}$ Sebab kalau kita menyaksikan akibat maraknya gejala kekerasan beragama selama ini, dan ini sungguh sangat aneh, buntut dari fenomena kekerasan atas nama agama, Islam banyak dituding oleh Barat sebagai biang keladi dari setiap ektrimisme, anarkisme dan terorisme. Padahal sejatinya, Islam syarat dengan ajaran kasih sayang dan cinta kasih. Islam memiliki ajaran fundamental seperti pluralisme, humanisme dan demokrasi.

TEOLOGIA, VOLUME 23, NOMOR 2, JULI-DESEMBER 2012 
SYAMSUL MA'ARIF: Pemahaman Keberagamaan dan Gerakan ...

${ }^{7}$ Sampai saat ini, sepertinya tidak terdapat definisi yang tunggal mengenai apa yang disebut sebagai minoritas atau kelompok minoritas. Dalam konteks Indonesia, terminologi minoritas bukan hanya sulit untuk menentukan definisinya secara ketat melainkan juga pada tataran batasan jumlahnya secara cacah jiwa. Bahkan dalam beberapa hal yang sangat konkret, kategorisasi minoritas yang disematkan oleh Negara terhadap kelompok tertentu tidak jarang menimbulkan reaksi balik yang cukup mengagetkan. Tetapi batasan minoritas kita bisa merujuk suatu definisi sebagai berikut: "A group of citizens of a State, constituting a numerical minority and in a nondominant position in that State, endowed with ethnic, religious and linguistic characteristics which differ from those of the majority of the population, having a sense of solidarity with one another, motivated, if only implicitly, by a collective will to survive and whose aim is ti achieve equality with the majority in fact and in law. Lihat dalam Proposal Concerning a Definition of the Term 'Minority'UN Document E/CN.4/Sub.2/1985/31 (1985).

${ }^{8}$ Islam adalah Agama mayoritas yang dipeluk oleh sekitar $85,2 \%$ penduduk Indonesia, yang menjadikan Indonesia negara dengan penduduk muslim terbanyak di dunia. Sisanya beragama Protetstan $(8,9 \%)$, Katolik (3\%), Hindu (1,8\%), Budha $(0,8 \%)$, dan lain-lain $(0,3 \%)$. Lihat dalam www.wikimedia.com.

${ }^{9}$ Tentang persoalan ini bisa juga dilihat dalam Sisi yang Tidak Diekspos Media dalam http://www.arrahmah.com. Di downlood pada hari Selasa, tanggal 28 Oktober 2008.

${ }^{10}$ Wawancara dilakukan pada malam hari, yaitu malam jum' at habis melakukan do'a dan istighosah bersama di Rumah Habib bin Mahdi.

${ }^{11}$ Tentang persoalan ini coba bandingkan dengan Andri Rosadi, Hitam Putih FPI, Jakarta: Nun Publisher, 2008, h. 88.

${ }^{12}$ Lihat dalam situs FPI: http://fpipetamburan.blogspot.com. Di downlood pada hari jumat, tanggal 24 September 2008.

13 Statemen ini diambil langsung dari Media Informasi \& Komunikasi (sementara/tidak resmi) dari Markas Besar DPP Front Pembela Islam. Dalam http://fpipetamburan.blogspot.com. Di downlood pada tanggal 16 Oktober 2008.

${ }^{14}$ Terus terang peneliti belum pernah melakukan serentetan spritual seperti ini, apalagi harus bersujud dengan waktu yang agak lama. Sebuah "pengalaman spritual" baru yang tidak dapat peneliti gambarkan, manfaat dan efeknya bagi jiwa. Peneliti yakin, setiap orang akan mengalami pengalaman spritual yang berbeda-beda. Dan hanya mereka sendiri yang dapat merasakan dan menggambarkan.

${ }^{15}$ Sayyid Qutb, Tafsir fi Zilāl al-Qur'ān, Kairo: Dār al-Shurūq, 1408H/1987 M, Jil. IV, Juz XIII, h. 2034.

${ }^{16}$ Ibnu Taimiyah, Majmū' al-Fatāāā, Riyad: Maṭabi’ al-Riyād, 1985, Juz XV, h. 185. 
SYAMSUL MA'ARIF: Pemahaman Keberagamaan dan Gerakan ... Edan".

${ }^{17}$ Untuk kelompok ini, FPI Surabaya menyebutnya dengan panggilan "Lia

${ }^{18}$ Statemen seperti ini beberapa kali diucapkan oleh habib dan jama'ah. Sebuah gambaran betapa bencinya mereka terhadap kelompok "SEPILIS".

${ }^{19}$ Mars FPI ini bersumber dari dokumentasi yang dimiliki FPI. Berkali-kali Ketua FPI Surabaya juga menjelaskan tentang anjuran berjihad untuk menolong agama Allah dan Rasul, juga didasarkan pada seruan FPI tentang Jihad.

${ }^{20}$ Tentang makna jihad dalam al-Qur'an terdapat berbagai perbedaan arti. Adakalanya jihad berarti menjaga iman dan kehormatan seseorang di tengah-tengah situasai yang gawat. Seperti dalam perintah Allah kepada nabi agar bersikap sabar terhadap orang-orang Mekkah, bersikap tenang, dan tidak melayani kekuatan dengan kekuatan; lih. QS. al-Ghasiyah [88]: 22, QS. al-'Ankabūt [29]: 18, dan QS. al-'Aṣr [103]: 3. Lalu pada fase Madinah (622-632 M), kata jihad mencakup perjuangan individu atau masyarakat dengan orang-orang Mekkah. Pada periode inilah jihad berarti perang Suci. Lihat dalam QS. al-'Ankabūt [29]: 69, "Barang siapa bersungguh-sungguh berjuang di jalan kami (Tuhan), maka kami akan menunjukkan kepada mereka jalan kami". Dan Surat 25: 52, artinya: "Janganlah tunduk kepada orang-orang yang tidak beriman, tetapi berjuanglah melawan mereka sebenar-benar jihad'.

${ }^{21}$ Salah satu anggota Jama' ah FPI ini mengaku berasal dari salah satu daerah di daerah JATIM, beliau telah lama mengikuti pengajian yang dilaksanakan oleh habib di rumahnya. Dahulu memang ia pernah nyantri di salah satu pondek pesantren salaf di lamongan JATIM. Karena tertarik dengan ajaran-ajaran habib, akhirnya memutuskan untuk bergabung FPI Surabya. Sekaligus dapat menimba ilmu keagamaan dari habib, katanya menjawab dengan polos.

${ }^{22}$ Tentang persoalan ini bisa dilihat dalam kitab Fath al-Qarīb karya Abū Shuja' dalam Ibnu Qāsim al-Ghāzi, Ḥāshiyah al-Bajūrí, juz II, dalam Kitāb al- Jihād, Semarang: Thoha Putera, tth., h. 262.

${ }^{23}$ Sedangkan kalau kita bandingkan dengan klasifikasi jihad dalam ilmu-ilmu fikih terdapat empat jenis jenis jihad yaitu: jihad hati (iman), jihad lisan (ucapan yang benar), jihad tangan (amal salih), dan akhirnya jihad pedang (perang suci).

${ }^{24}$ Seperti telah dikatakan dan dijelaskan oleh para kelompok FPI Surabaya selama peneliti mengadakan penelitian.

${ }^{25}$ Tentang persoalan ini, dari pihak FPI juga telah mengakui bahwa sejak FPI melakukan gerakan menentang kemungkaran, maka sejak itu tidak hentinya, istilahistilah yang dilontarkan kepada FPI, mulai dari Islam garis keras, Islam fundamentalis, anarkis, main hakim sendiri, sampai pada tingkat teroris. Akan tetapi semua hujatan yang dilontarkan kepada FPI, tidak menyurutkan langkah para aktivis dakwah itu. Lihat dalam http://www.eramuslim.com. Indonesia).

${ }^{26}$ Untuk menyebut salah satu kelompok ini adalah HTI (Hizbut Tahrir

${ }^{27}$ Said Aqiel Siradj, Islam Kebangsaan: Fiqih Demokartik Kaum Santri, Jakarta: Pustaka Ciganjur, 1999, h. 74.

TEOLOGIA, VOLUME 23, NOMOR 2, JULI-DESEMBER 2012 
SYAMSUl MA'ARIF: Pemahaman Keberagamaan dan Gerakan ...

${ }^{28}$ Muhammad Daud Ali, "Pendidikan Agama Islam", Jakarta : PT. Raja Grafindo Persada, 1998, h. 50-52.

${ }^{29}$ Secara garis besar hasil wawancara dengan Ketua FPI Surabaya tentang shari'ah, beliau memberikan definisi syari'at Islam adalah hukum-hukum peraturanperaturan) yang diturunkan Allah swt. untuk umat manusia melalui Nabi Muhammad saw. baik berupa al-Qur'an maupun Sunnah Nabi yang berwujud perkataan, perbuatan, dan ketetapan, atau pengesahan.

${ }^{30}$ Sayyid Abū Bakar, Kifāyah al-Atqiyā' wa al-Minhāj al-Shifă', Semarang: Alawiyah, tt, h. 9.

${ }^{31}$ Intisari wawncara dengan Ketua FPI Surabaya terkait Syari'ah Islamiyah.

${ }^{32}$ Kalimat ini sebagaimana diungkapkan oleh Ketua FPI Surabaya dan para anggotanya.

${ }^{33}$ Untuk memperoleh Buku ini, penulis sangat berterimakasih kepada Ketua FPI Surabaya yang dengan "tulus" telah mengirim ke rumah peneliti beserta dokumendokumen penting tentang gerakan FPI. Buku Pledoi Ketua FPI ini, pernah disampaikan di PN Jakarta Pusat pada tanggal 20 Syawwal 1429 H/20 Oktober 2008 M.

\section{DAFTAR PUSTAKA}

Abū Bakar, Sayyid, Kifäyah al-Atqiyā' wa al-Minhāj al-Shifä', Semarang: Alawiyah, tth.

Ali, Muhammad Daud, "Pendidikan Agama Islam", Jakarta : PT. Raja Grafindo Persada, 1998.

Cunningham, F., Theories of Democracy: A Critical Introduction, New York: Routledge, 2002.

Ghāzì, Ibn Qāsim Ḥāshiyah al-Bajūrì, juz II, Semarang: Thoha Putera, tth.

Gauf AF, Ahmad, "Islam Progresif: Wacana Pasca Arus Utama", dalam Jurnal Taswirul Afkar, edisi No. 22 Tahun 200

Ibn Taimiyah, Majmū' al-Fatāwā, Juz XV, cet. I., Riyād: Maṭabi' alRiyād, 1985.

Kurzman, Charles, Wacana Islam Liberal: Pemikiran Islam Kontemporer tentang Isu-isu Global, Jakarta: Paramadina, 2001.

Piscatori, James P., Islam in a World of Nation-State, Cambridge, New York. etc.: Cambridge Univercity Press, 1988. 
SYAMSUL MA'ARIF: Pemahaman Keberagamaan dan Gerakan ...

Quṭb, Sayyid, Tafsīi fi Zilāl al-Qur'ān, Cet. XIV, , Jilid IV, Juz XIII, Kairo: Dār al-Shurüq, 1408H/1987 M.

Rosadi, Andri, Hitam Putih FPI, Jakarta: Nun Publisher, 2008.

Siradj, Said Aqiel, Islam Kebangsaan: Fiqih Demokartik Kaum Santri, Jakarta: Pustaka Ciganjur, 1999.

TEOLOGIA, VOLUME 23, NOMOR 2, JULI-DESEMBER 2012 